\title{
CUTTING-TOOL PERFORMANCE IN THE END MILLING OF CARBON-FIBER-REINFORCED PLASTICS
}

\author{
ZMOGLJIVOST REZILNEGA ORODJA PRI REZKANJU PLASTIKE, \\ OJAČANE Z OGLJIKOVIMI VLAKNI
}

\author{
Ondřej Bílek, Soňa Rusnáková, Milan Žaludek \\ Faculty of Technology, TBU Zlín, Nám. T.G.M 5555, 76001 Zlín, Czech Republic \\ bilek@ft.utb.cz \\ Prejem rokopisa - received: 2015-06-30; sprejem za objavo - accepted for publication: 2015-09-09
}

doi:10.17222/mit.2015.153

\begin{abstract}
Carbon-fiber-reinforced plastics (CFRPs) are no longer the exclusive domain of aerospace industries and nowadays find more applications in the automotive and consumer industries. The growing volume of these materials increases the need for their efficient machining. However, the machinability of CFRPs is a rather complex task due to the heterogeneity and the considerable number of parameters influencing the cutting process. The cutting tool has long been recognized as an important factor influencing both surface quality and dimensional accuracy. Hence, in this paper, tool performance is investigated in the end milling of CFRPs. The effect of tool geometry and coatings on the cutting forces, dimensional accuracy and surface quality were experimentally examined for side and slot milling.
\end{abstract}

Keywords: CFRP, composites, end mill, surface quality, cutting forces

Plastika, ojačana z ogljikovimi vlakni (CFRP), dosedaj ekskluzivna domena letalske industrije, se v zadnjem času bolj pogosto uporablja tudi $\mathrm{v}$ strojništvu, $\mathrm{v}$ avtomobilski industriji in $\mathrm{v}$ potrošništvu. Z naraščanjem uporabe teh materialov, narašča tudi potreba po učinkoviti strojni obdelavi. Vendar pa je strojna obdelava CFRP-a precej kompleksna naloga zaradi heterogenosti in številnih parametrov, ki vplivajo na proces rezanja. Že dolgo je znano, da je rezilno orodje pomemben faktor, ki vpliva na kvaliteto površine in dimenzijsko natančnost. Zato je v članku preiskovana zmogljivost orodja pri rezkanju plastike, ojačane z ogljikovimi vlakni. Pri bočnem in utorovnem rezkanju je bil preiskovan vpliv geometrije orodja in površinske prevleke na sile rezanja, dimenzijsko zanesljivost in na kvaliteto površine.

Ključne besede: CFRP, kompoziti, čelni rezkar, kvaliteta površine, sile rezanja

\section{INTRODUCTION}

Milling is the key manufacturing operation for the successful machining of fiber-reinforced plastic parts, which ensures dimensional and qualitative requirements. Milling is used, as a rule, as an edge-trimming operation, or a slotting/routing process to produce complex contours.

Composite materials such as carbon fiber-reinforced plastics (CFRPs) are heterogeneous materials composed of dissimilar constituents, where the resulting mechanical properties are more than the sum of the characteristics of the individual components. A plastic matrix of
CFRPs is reinforced by carbon fibers entirely, resulting in a high specific strength and stiffness throughout the lifetime of the components, together with electrical and magnetic resistance. This makes them interesting for applications in the automotive and aircraft industries, in railway and ship building, medical applications and the space industry. ${ }^{1,2}$

CFRP composites replace traditional metallic materials; however, their machinability is fundamentally different and the cutting mechanism is still under investigation. The machining properties are influenced by the heterogeneity and anisotropy of the composite material. The mechanical properties of the matrix are strongly

Table 1: Characteristics of the end mill

Tabela 1: Značilnosti steblastih rezkarjev

\begin{tabular}{|c|l|c|c|c|c|}
\hline & \multicolumn{1}{|c|}{ Tool cutting zone } & Cutting diameter $(\mathrm{mm})$ & Helix angle $\left(^{\circ}\right)$ & Rake angle $\left(^{\circ}\right)$ & Coating \\
\hline T1 & Down-cut spiral with chip-breaker & $5.81 \pm 0.07$ & 15 & 0 & PCD \\
\hline T2 & Four flute up-cut spiral & $5.96 \pm 0.02$ & 10 & 6 & PCD \\
\hline T3 & Cross-pitch spiral & $5.92 \pm 0.01$ & 25 and 27 & 7 & PCD \\
\hline T4 & Cross-pitch spiral & $5.91 \pm 0.02$ & 25 and 27 & 7 & uncoated \\
\hline T5 & Up-cut spiral with chip-breaker & $5.96 \pm 0.03$ & 47 & 10 & Multilayered \\
\hline T6 & Right- and left-hand spiral & $5.94 \pm 0.02$ & 13 & 30 & Multilayered \\
\hline T7 & Cross-pitch spiral & $5.97 \pm 0.02$ & 10 & 0 & PCD \\
\hline T8 & Three flute upcut spiral & $5.91 \pm 0.03$ & 15 & 30 & PCD \\
\hline
\end{tabular}


temperature dependent, while the carbon fibers can withstand temperatures up to $3000{ }^{\circ} \mathrm{C}$, and during machining cause considerable tool wear. ${ }^{3}$

Machining CFRPs brings with it certain difficulties, such as layer delaminations, fiber pull-out, uncut fibers, degradation and burning of the plastic matrix. ${ }^{4-7}$ Tool manufacturers and scientists recommend carbide tools with a polycrystalline diamond (PCD) coating for CFRP material machining. These tools ensure high productivity with a sufficient tool life. Unfortunately, the cost of PCD tools is six times higher than uncoated tools, whereas tool life is only three times longer. ${ }^{8}$ End mills usually have a very special design suitable for the milling of CFRPs. ${ }^{9}$ Helical end mills with two flutes are suitable for rigid or back-supported parts. ${ }^{10}$ Compression end mills with two sets of left-hand and right-hand flutes limit the delamination and burrs on the cut edges. ${ }^{11}$ Furthermore, the machining of flexible parts by multi-tooth end mills eliminates the cutting force along the $Z$-axis, thereby reducing the deflection and vibration of the part. ${ }^{8}$ In-between are helical mills with a chip-breaker geometry ${ }^{12}$ that shears fibers and shortens chips with the simultaneous reduction of vibrations.

In this work we compare the performance of end mills on the resulting surface quality, dimensional accuracy and cutting forces in the slotting and side milling of CFRPs.
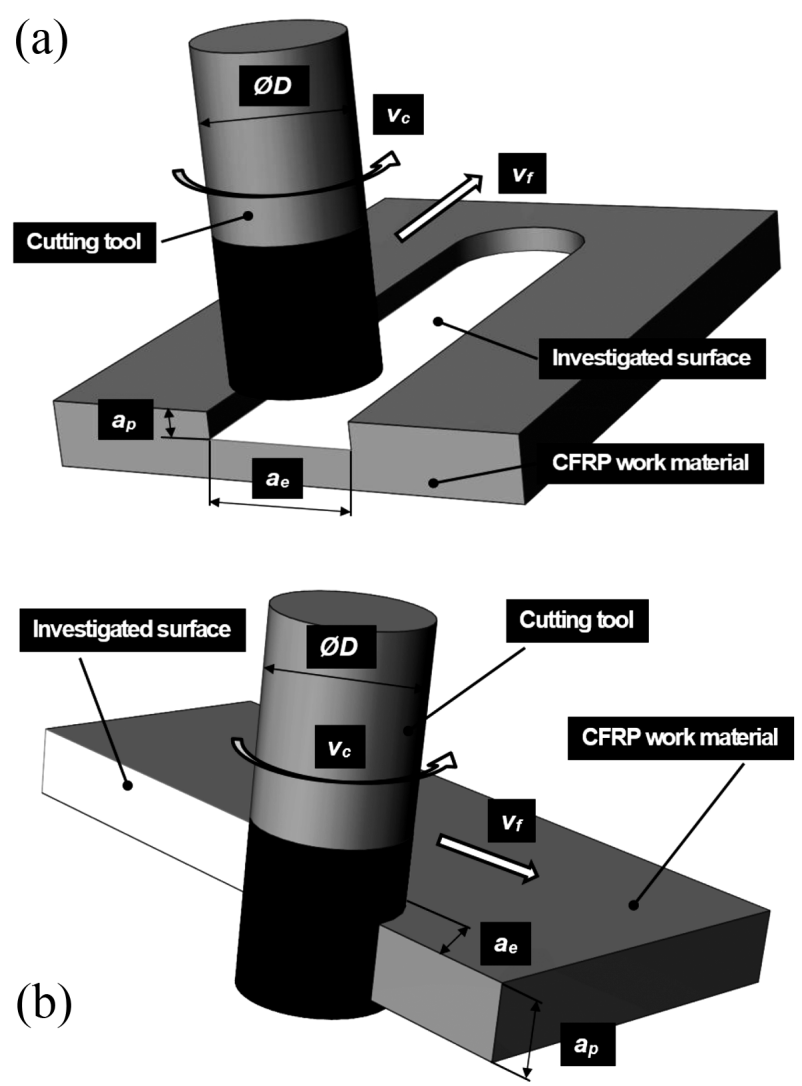

Figure 1: a) slot milling and b) side milling Slika 1: a) rezkanje utora in b) bočno rezkanje

\section{EXPERIMENTAL PROCEDURE}

The composite samples used in the experimental investigation were produced by vacuum infusion technology. The carbon fiber and the epoxy were supplied by KORDCARBON CZ. The fabric was Toray HS 3K 200 tex, a balanced twill bidirectional $\left(0-90^{\circ}\right)$ weave and $380 \mu \mathrm{m}$ thick. The epoxy used in the fabrication was the commercially available Havel L285 epoxy system.

Fourteen layers of fabric were used to fabricate the work samples with an average thickness of $4 \mathrm{~mm}$. Overall, the CFRP composite average flexure strength was $501 \mathrm{MPa}$, the modulus of elasticity was $43,300 \mathrm{GPa}$ and the tensile strength was $378 \mathrm{MPa}$.

The experiment was carried out by using eight carbide end mills acquired from different producers (SECO, WNT, KTOOLS). The required tool cutting diameter was $6 \mathrm{~mm}$. In this article the end mills are referred to as T1-T8 and were concerned for special applications such as the milling of composites with a wide range of compositions. Their geometry is summarized in Table $\mathbf{1 .}$ Except for the T4 tool, the end mills were coated to withstand the machining of a highly abrasive work material.

A CNC milling machine C-442 HWT with a $1.0-\mathrm{kW}$ spindle power and high-speed spindle of $416.16 \mathrm{~Hz}$ was used to perform the experiments. Part of the program was created to ensure the repeatability and accuracy of the experiment. The machining was divided into two consecutive methods, first slot milling (Figure 1a) and next upcut side milling (Figure 1b) of the CFRP work material. The machining conditions are given in Table $\mathbf{2}$ for both methods. A coolant was not used and the tool cutting length was $150 \mathrm{~mm}$ in both methods. A tool-wear evaluation was carried out at the end of every set of experiments. First, each tool was milling a slot and subsequently a side of work material, so that the tool displacement towards the bottom surface of the work material was $2 \mathrm{~mm}$.

Table 2: Cutting conditions

Tabela 2: Pogoji rezanja

\begin{tabular}{|c|c|c|c|c|}
\hline Method & $\begin{array}{c}\text { Cutting } \\
\text { speed } \\
v_{c}(\mathrm{~m} / \mathrm{min})\end{array}$ & $\begin{array}{c}\text { Feed rate } \\
v_{f}(\mathrm{~mm} / \mathrm{min})\end{array}$ & $\begin{array}{c}\text { Depth of } \\
\text { cut } \\
a_{p}(\mathrm{~mm})\end{array}$ & $\begin{array}{c}\text { Width of } \\
\text { cut } a_{e}(\mathrm{~mm})\end{array}$ \\
\hline Slot milling & 100 & 550 & 1.25 & $a_{e}=D$ \\
\hline Side milling & 100 & 550 & 2.0 & 4.0 \\
\hline
\end{tabular}

Cutting forces were measured on the strain-gauge dynamometer in the direction of the feed-rate vector (force $F f$ ) and perpendicularly to $F f$ (force $F f n$ ). The signal from dynamometer was processed by a Spider8 data-acquisition system and the evaluations were made through a PC with Conmes Spider software, as illustrated in Figure 2.

The dimensional accuracy of the machined slot was evaluated using a Mitutoyo caliper. The surface quality was measured with a portable surface-roughness tester Mitutoyo SJ-301, according to ISO 4287 on the high- 


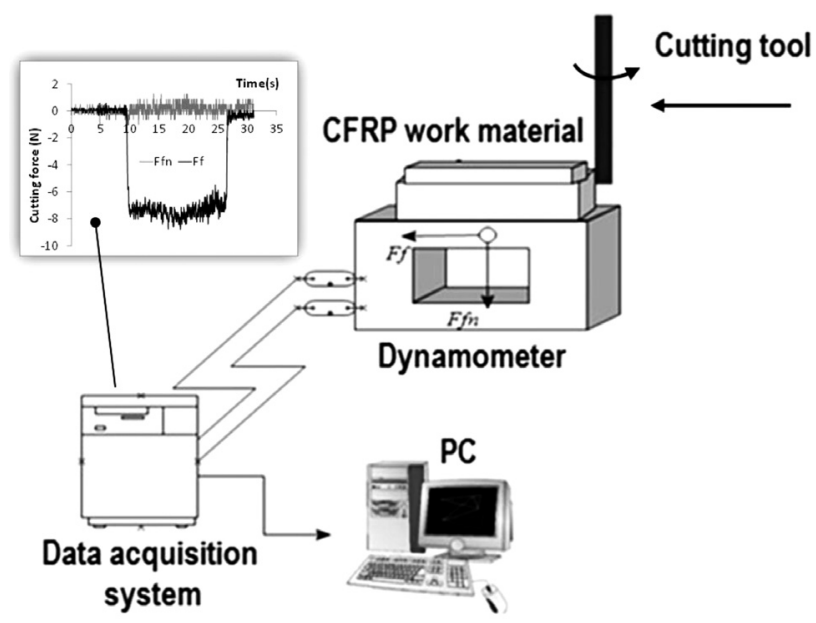

Figure 2: Experimental set up for milling CFRPs

Slika 2: Eksperimentalni sestav za rezkanje CFRP

lighted areas at the bottom of the slot (Figure 1a) and the side surface (Figure 1b). The measurements repeated were 15 times at different surface locations in the direction of the feed-rate vector that was identified as the direction of highest roughness. The roughness parameter $R a$ was considered as an evaluation parameter for the surface quality according to ISO.

\section{RESULTS AND DISCUSSION}

\subsection{Cutting forces}

All the force measurements were worth a maximum of $4.86 \%$ of variance. The results were graphically summarized in Figure 3 and $\mathbf{4}$. There is a significant difference between the end mills, moreover not the only one is suitable both as side and slot milling. Tool T6 with right- and left-hand spirals reached the lowest values Ff when slot milling (Figure 3) and the second best value as for T4 tool without coating. Higher values of $F f$ and Ffn were achieved by the same T3 tool with the coating. This may be due to increased adhesion of work material to the PCD coating material.

Tools T1, T3, T8 keep along the average. Conversely, the highest values of $F f$ achieved tool T2 and T7,

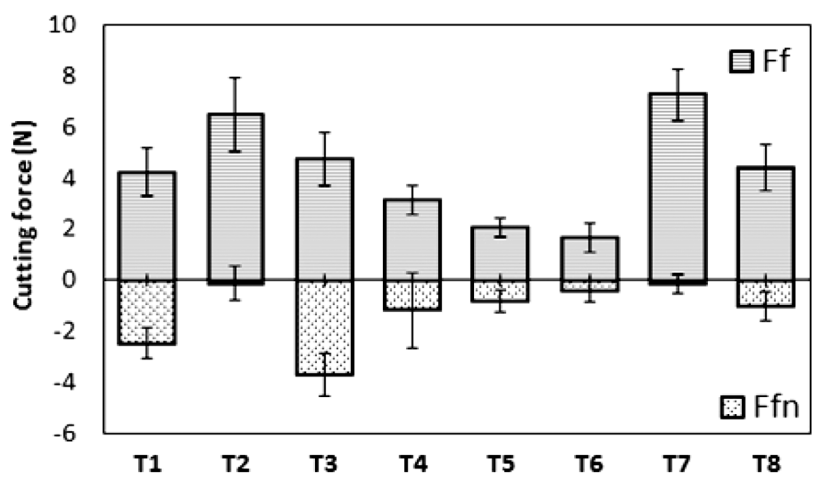

Figure 3: Cutting forces for slot milling of CFRP work material Slika 3: Sile rezanja pri rezkanju utora v CFRP obdelovanec

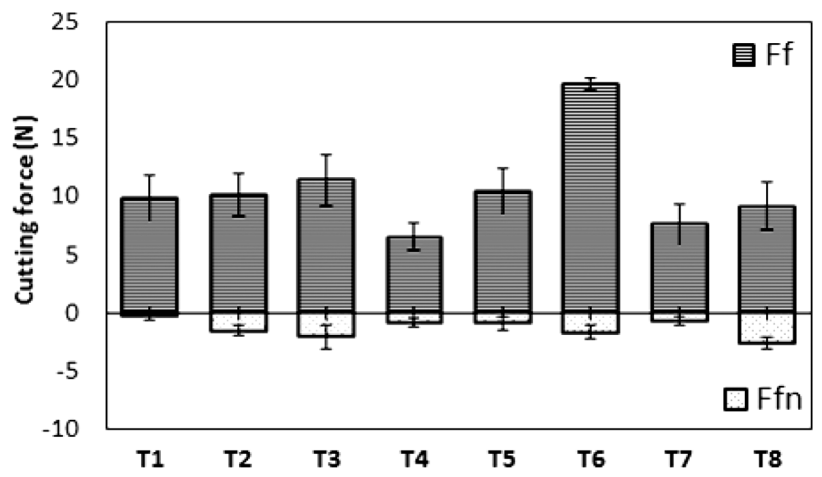

Figure 4: Cutting forces for side milling of CFRP work material Slika 4: Sile rezanja pri bočnem rezkanju CFRP obdelovanca

although with different flute geometries, but with the same helix angle of $10^{\circ}$, despite the normal force $F f n$ was the lowest one. The helix angle probably improves the chip removal at the bottom of the slot; however, the tool is more power loaded in the feed direction. In the case of higher cutting depths we can expect a higher tool bend, but without a buckling effect.

When side milling, the non-significant Ffn force was not evaluated, yet was mentioned in Figure 4. The force $\mathrm{Ff}$ is more than 2 times higher than when slot milling. The smallest $F f$ value comes from the T4 tool without coating, the worst was the T6 tool with a right- and left-hand hand spiral. The reason for this may be in the compression effect of contra-rotating spirals, becoming for these tools. Although the flutes' geometry for the T1, T2, T5 and T8 tools was dissimilar, the feed-force characteristics were almost identical and quite balanced.

\subsection{Surface roughness}

The dynamometric investigation was followed by surface-roughness measurements of the $R_{\mathrm{a}}$ parameter.

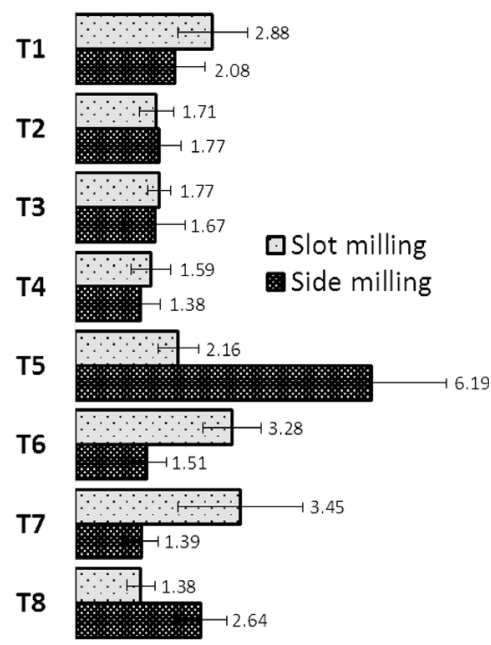

Figure 5: Surface roughness $R_{\mathrm{a}}$ for slot and side milling Slika 5: Hrapavost površine $R_{\mathrm{a}}$ pri rezkanju utora in pri bočnem rezkanju 


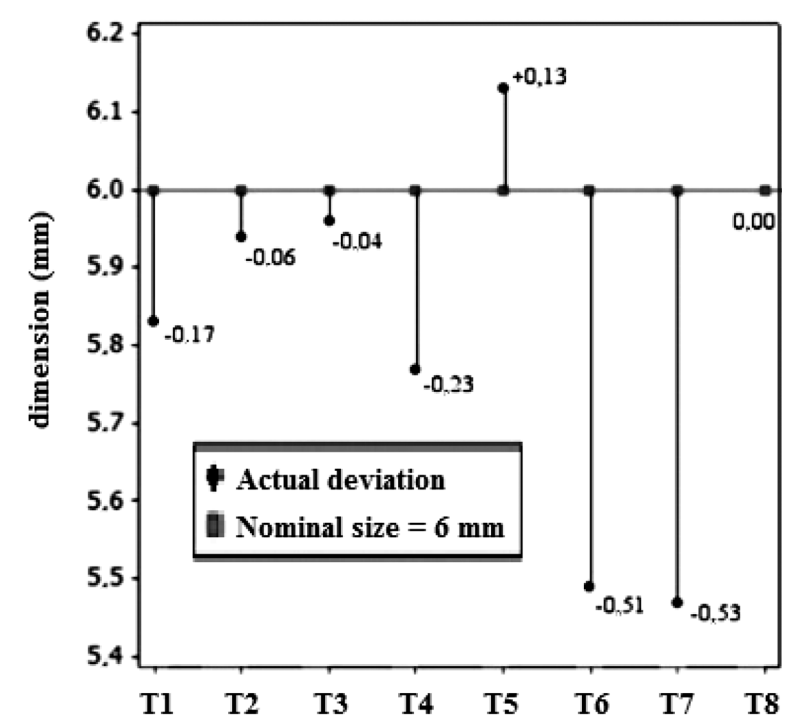

Figure 6: Dimensional accuracy of the width of the slot

Slika 6: Dimenzijska natančnost širine utora

The results are shown in Figure $\mathbf{5}$ for the side and slot milling.

The lowest average value of $R_{\mathrm{a}}=1.38 \pm 0.40 \mu \mathrm{m}$ was on the side surface made by the uncoated T4 tool and the same value $R_{\mathrm{a}}=1.38 \pm 0.29 \mu \mathrm{m}$ is at the bottom of the slot by the T8 tool. The T5 tool had the highest and most unsatisfactory effect for side milling, where the roughness value was $R_{\mathrm{a}}=6.19 \pm 1.57 \mu \mathrm{m}$. It is the only tool with an upcut spiral in the experiment and is actually a production tool recommended for rough machining. Approximately half values of $R_{\mathrm{a}}=3.45 \pm 1.30 \mu \mathrm{m}$, but highest for slot milling, was made with the cross-pitched $\mathrm{T} 7$ tool with a $0^{\circ}$ rake angle.

\subsection{Dimensional accuracy}

Since end mills should have a $6 \mathrm{~mm}$ diameter, it was expected that the resulting dimension of the slot would be given with a certain accuracy close to that value. As it turned out, this was not entirely true for slot milling of CFRP work material, as can be seen in Figure 6.

In most cases, the resulting dimension of the slot is smaller than the desired nominal size. On the one hand, it could be given by the true tool diameter (Table 1) that was smaller than the producer specification. In contrst, for the T5 tool with an upcut spiral we found that the slot was about $0.13 \mathrm{~mm}$ wider. This excludes the eventuality that a smaller tool diameter was made on purpose, taking into account the CFRP material's behavior. Finally, the T8 tool made it possible to achieve a superior slot accuracy, but otherwise lagged behind in terms of cutting efficiency and surface quality.

\section{CONCLUSIONS}

In this work the cutting performance of the end mills in the CFRPs milling has been presented, taking into account the force, surface roughness and dimensional measurements. After the testing of eight end mills several conclusions can be drawn:

- an upcut spiral can cause considerably worse surface quality together with an increment of the slot dimension,

- PCD-coated tools for CFRPs machining has a lower cutting efficiency due to a different friction characteristic than the uncoated tools,

- tools with left-hand and right-hand spirals recommended for side milling, result in up to twice the cutting force,

- to ensure compliance with the required dimensions, accuracy and stability it is necessary to include an offset (by part program, cutting conditions, thermal field) for the CFRPs tool individually.

\section{REFERENCES}

${ }^{1}$ E. Uhlmann, F. Sammler, S. Richarz, F. Heitmüller, M. Bilz, Machining of Carbon Fibre Reinforced Plastics, Procedia CIRP, 24 (2014), 19-24, doi:10.1016/j.procir.2014.07.135

${ }^{2}$ S. Rusnakova, L. Fojtl, M. Zaludek, V. Rusnak, Design of material composition and technology verification for composite front end cabs, Manufacturing Technology, 14 (2014), 607-611

${ }^{3}$ O. Pecat, R. Rentsch, E. Brinksmeier, Influence of milling process parameters on the surface integrity of CFRP, Procedia CIRP, 1 (2012), 466-470, doi:10.1016/j.procir.2012.04.083

${ }^{4}$ M. H. El-Hofy, S. L. Sooa, D. K. Aspinwalla, W. M. Simb, D. Pearsonc, P. Hardend, Factors affecting workpiece surface integrity in slotting of CFRP, Procedia Eng., 19 (2011), 94-99, doi:10.1016/ j.proeng.2011.11.085

${ }^{5}$ W. Hintze Wolfgang, D. Hartmann, C. Schütte, Occurrence and propagation of delamination during the machining of carbon fibre reinforced plastics (CFRPs) - An experimental study, Compos. Sci. Technol., 71 (2011), 1719-1726, doi:10.1016/j.compscitech. 2011.08.002

${ }^{6}$ Y. Karpat, O. Bahtiyar, B. Deer, Mechanistic force modeling for milling of unidirectional carbon fiber reinforced polymer laminates, Int. J. Mach. Tools Manuf., 56 (2012), 79-93, doi:10.1016/ j.ijmachtools.2012.01.001

${ }^{7}$ R. Teti, Machining of Composite Materials, CIRP Annals - Manufacturing Technology, 51 (2002), 611-634, doi:10.1016/S00078506(07)61703-X

${ }^{8}$ L. N. López de Lacalle, A. Lamikiz, F. J. Campa, A. Fdz. Valdivielso, I. Etxeberria, Design and Test of a Multitooth Tool for CFRP Milling, J. Compos. Mater., 43 (2009), 3275-3290, doi:10.1177/0021998309345354

${ }^{9}$ Y. G. Wang, X. P. Yan, X. G. Chen, C. Y. Sun, G. Liu, Cutting Performance of Carbon Fiber Reinforced Plastics Using PCD Tool, Advanced Materials Research, 215 (2011), 14-18, doi:10.4028/ www.scientific.net/AMR.215.14

${ }^{10}$ J. P. Davim, P. Reis, Damage and dimensional precision on milling carbon fiber-reinforced plastics using design experiments, J. Mater. Process. Technol., 160 (2005), 160-167, doi:10.1016/j.jmatprotec. 2004.06.003

${ }^{11}$ P. Masek, P. Zeman, Effective milling of composites with thermoplastic matrix, MM Prumyslove spektrum, 6 (2013), 60-64

${ }^{12}$ S. Legutko, G. Krolczyk, J. Krolczyk, Quality evaluation of surface layer in highly accurate manufacturing, Manuf. Technol., 14 (2014), $50-56$ 